\title{
Nobel officials recoil from expenses offer
}

\section{David Cyranoski, Tokyo}

An offer by a Japanese government organization to pay for Nobel Foundation officials to visit prize-hungry Japan is ruffling feathers in Stockholm.

The Science Council of Japan says it will pay for Nobel laureates and representatives - including the director and secretary of each of the Nobel Foundation's three scientific committees - to travel to Tokyo next March for a forum celebrating 100 years of the Nobel prizes.

But one of the invited officials says the offer to cover the trip's expenses is unnecessary and inappropriate - especially at a time when Japan has set a national target of winning 30 Nobel prizes in the next 50 years.

"The invitations pose an ethical problem for me as there is such an outspoken Japanese policy to acquire Nobel prizes," says Anders Bárány, a physicist at Stockholm University and secretary of the physics committee. "The Nobel Foundation has enough money to pick up the bill."

The government's Nobel target has been attacked by some Japanese academics as inappropriate (see Nature 413, 562; 2001). But others have defended it as a harmless goal that will spur researchers and help to ensure political support for science in Japan.

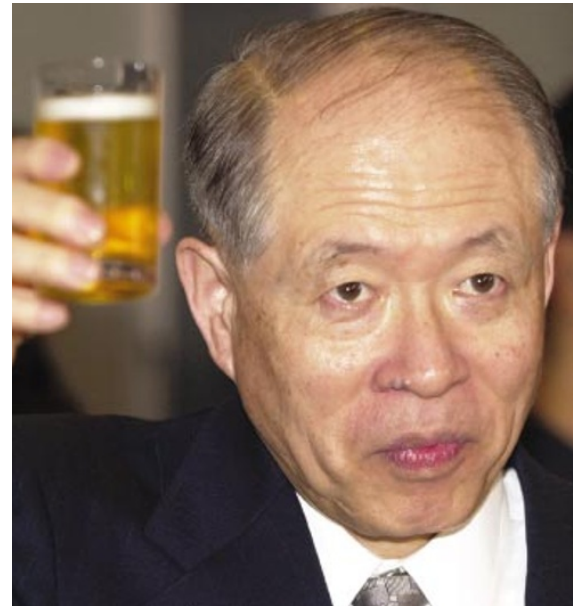

Role model: Ryoji Noyori won a Nobel prize this year, but Japan wants 30 more like him by 2050 .

The March forum will coincide with the opening of a touring exhibition on the Nobels, for which Japan is the first stop. "In other international events, it has been customary to cover invitees' costs," says Kiyoshi Kurokawa, vice-president of the science council. "This isn't special treatment." But he adds that the council "will wait to see how the Nobel Foundation wants to handle expenses" before it actually pays them.
Not all Nobel Foundation officials are concerned by the proposed arrangement. "For travel and hotel expenses to be covered by the inviting organizers seems to be standard procedure," says Michael Sohlman, executive director of the Nobel Foundation.

Bárány says he supports the forum itself, but fears a repeat of the controversy that attached itself to the 1986 award of the medicine prize to Rita Levi-Montalcini of Italy's Institute of Cell Biology in Rome. It was later alleged in Swedish newspapers that a Nobel committee member had accepted an expenses-paid trip from a drug company that wanted Levi-Montalcini to get the prize. "Investigations showed that the Nobel committee member just failed to realize that this kind of question can come up," says Bárány, adding that this was "silly, as each committee has money for this kind of travel anyway".

But there are no clear guidelines for what committee members can or cannot accept in terms of invitations. Bárány says he wants the Nobel Foundation to address this issue quickly. But Sohlman does not think it is a problem. "We have been relying on the common sense of the members of the Nobel institutions for a hundred years now," he says, "and have reason to continue to do so."

\section{Mathematicians poised for major funding boost}

\section{Erica Klarreich}

Increased support for mathematics research is set to form a central plank of the 2003 budget for the US National Science Foundation (NSF) to be proposed by President George W. Bush in February.

Mathematicians hope that the increase will allow the agency to deliver larger grants. Compared with other disciplines, where the median NSF grant is $\$ \mathbf{8 0 , 0 0 0}$ per year, mathematics' median is only about $\$ 35,000$

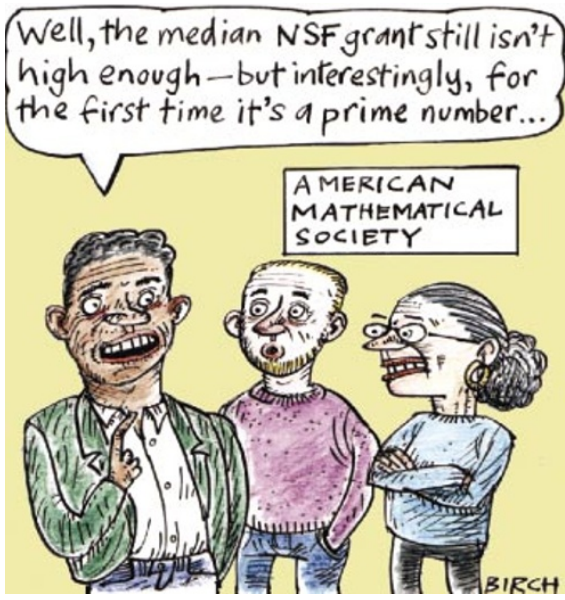

— described as "a disgraceful number" by Philippe Tondeur, head of the NSF's mathematics division.

Back in October 2000, NSF director Rita Colwell called for the mathematics budget — \$121 million in 2001 - to quadruple by 2007 (see Nature 407, 931; 2000). But the 2002 budget will only increase the subject's allocation by about $\$ 20$ million, far short of Colwell's goal. Tondeur says that he hopes the 2003 figure will be "on a higher scale" than that for 2002. Senior officials in the agency say he will not be disappointed.

The government cannot release details of the budget in advance, but Sam Rankin, associate executive director of the American Mathematical Society (AMS), says that mathematicians are looking for a division budget of as much as $\$ 200$ million.

The money would pay for new interdisciplinary projects linking mathematics to biology, computer science and geosciences, Tondeur says. It would also allow the division to expand its programme of Grants for Vertical Integration of Research and Education, launched in 1999. This programme, which already funds 31 departments, encourages interaction between senior faculty, postdoctoral researchers, graduate students and undergraduates.

US mathematicians complain that funding for their discipline has been declining since the 1970s as defence agencies, which used to fund much of their work, became less supportive of basic research. The NSF now accounts for nearly three-quarters of federal funding of mathematics. But only about 1,500 mathematicians - a small fraction of academic mathematicians - get NSF grants each year, according to Rankin.

"The backbone of mathematics is the individual investigator, and the system has not kept pace with the number of strong investigators in recent years," says David Eisenbud, director of the Mathematical Sciences Research Institute in Berkeley, California.

The new initiative should create a very different picture, Tondeur says. "It's going to be a really adventurous period for the mathematical sciences," he says. "There's a growing perception that mathematics is an enabling discipline for science, technology and engineering." 